\title{
'WHAT IS THE PLURAL OF MOUSE?' AND OTHER UNHELPFUL QUESTIONS FOR MORPHOLOGISTS
}

\author{
Laurie BAUER (ID $\boldsymbol{M}$ \\ Victoria University of Wellington, New Zealand
}

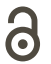

OPEN ACCESS

EDITORS

- Miguel Oliveira, Jr. (UFAL)

- René Almeida (UFS)

REVIEWERS

- Seung Hwa Lee (UFMG)

- Indaiá Bassani (UNIFESP)

DATES

- Received: 08/30/2020

- Accepted: 09/27/2020

- Published: 02/07/2021

HOW TO CITE

BAUER, Laurie (2021). 'What Is the Plural of Mouse?' and Other Unhelpful Questions for Morphologists. Cadernos de Linguística, v. 2, n. 1,p. 01-16.

\section{ABSTRACT}

In this paper a number of questions about the morphology of English are posed, and it is shown that each of them carries presuppositions which may be theoretically unsupportable, because there is data which suggests that they are wrong. If we do not make theoretical assumptions, but let ourselves be guided by the data, our theoretical statements may have to be modified, sometimes in crucial ways. While this paper is, to the extent that it asks morphological questions, a contribution to what a morphological theory should comprise, the more general conclusion is that the way in which we frame questions that we expect our theory to answer can have implications for our findings, and that it is always worthwhile querying the content of our fundamental questions.

\section{RESUMÉ}

I denne meddelelse, stiller jeg nogen spørgsmål om engelsk morfologi, og viser, at hvert spørgsmål medfører præsuppositioner, som ikke kan støttes konsekvent med fakta fra sproget. Hvis vi lader os styre af de sproglige fakta, bliver vi nødt til at lave om på vores teoretiske stillinger, af og til med vigtige konsekvenser for teorien. Idet meddelelsen handler om morfologiske spørgsmål, udgør den et bidrag til morfologisk teori. Men moralen med fremlæggelsen er bredere: Vi er nødt til hele tiden stille spørgsmål om vores teorier, også de mest grundlæggende ideer i vores 
teorier, hvis ikke vi vil føres på vildspor, og hvis vi vil forbedre vores forståelse af vores emne.

\section{KEYWORDS}

English; Morphology; Productivity; Overabundance; Allomorphy.

\section{NØGLEORD}

Engelsk; Mofologi; Produktivitet; Morfologisk Overflod; Allomorfi. 


\section{INTRODUCTION}

This paper is ostensibly a paper about morphology. I ask questions and provide evidence about morphological phenomena. However, the paper is really more general than that. It is a paper about the way in which our presuppositions about the way the world is, the way a language is, influence our theoretical approach to data, and how that can lead us astray. It is, if you like, a reminder that we must always re-evaluate the fundamentals of our theoretical machinery, and be prepared to jettison any parts of it which are misleading, or damaging to our desire for scientific progress. In my experience, it is often the most fundamental parts of our theoretical base which are most deeply embedded in our assumptions, and yet which are hardest to explain and justify. Furthermore, it is close examination of the data - in our case the fundamental data of linguistic descriptions that can show us where we have gone wrong, where we may need to stop and rethink our position. The re-evaluation of the phoneme since the early 1960s and the re-evaluation of the morpheme since the early 1970s provide examples of the kind of radical changes that such reconsideration can make to linguistic theory.

In this paper I present half-a-dozen questions which morphologists might be asked, and which, I suggest, may not be particularly helpful because they lead us to frame our theoretical endeavours in ways which are ultimately not likely lead to a sustainable theoretical position. The challenge is twofold. For morphologists, the challenge is to pick up these ideas (or develop others) and see where they might lead in a theoretical perspective. For linguists in other disciplines, the challenge is to find equivalent fundamental problems in the theory of their own area of expertise, and to see how linguistic theory as a whole might be improved upon. The questions I ask below are formulated with relation to English, but I would expect the same questions to arise from the study of other languages, and I would also expect the study of other languages to give rise to a wider range of questions with theoretical import.

\section{QUESTION 1: WHAT IS THE PLURAL OF MOUSE?}

Virtually any grammar of English will provide the information that mouse is one of a small number of nouns in English whose plural is formed by a historical process of umlaut, and that its plural form is mice. See, for example, STRANG (1969, p. 87), QUIRK, et al. (1972, p. 178), PALMER; HUDDLESTON; PULLUM (2002, p. 1589); BAUER; LIEBER; PLAG (2013, p. 132) do provide some limited caveats. And if we are talking about rodents in the kitchen or in the laboratory, and they are being discussed seriously in standard English, that is the form that is most likely to be used. But if we stop there, we are missing something about the word 
mouse in English and its plural. Because if we are discussing the kind of mouse that it attached to our computer, it is less clear that the automatic answer will be mice. WEHMEIER (2000) notes, for this meaning, that the plural can also be mouses. And if we consider the Disney characters Mickey and Minnie Mouse, and think of them less as leading actors and more as the stuffed-toy representations of these actors sold in Disney stores round the world, my students (and I) feel quite sure that these are Mickey Mouses (although we will need to revise this conclusion in the light of further evidence in a while). We can push this analysis further. In the late 1950s and early 1960s, Hanna-Barbera produced a number of cartoon TV shows starring two rodents called Pixie and Dixie and their arch-enemy Mr Jinks, the cat. The cat, inevitably, came off worst in their encounters, which would lead him to exclaim, 'I hate thoses meeces to pieces!' Here we have a third plural form, albeit one used as a joke and in a limited setting (or with reference to that limited setting). But even jokes are part of the language, if not high-frequency parts of the language. I can also report that when a poster advertising an oral presentation of this material was posted in my own university, some kind person answered the question in the title by writing on one of the posters: the answer provided was mices. This form is one which might be heard not only from students, but also from children learning English.

In summary, mouse does not have a single plural in English. It has a range of plurals, of which I have cited four. They are not all equally likely, but even in context we may not be able to predict absolutely which one will occur. This variability can be shown even more clearly if we look beyond the slight evidence I have provided to rather more robust sources of evidence.

We can begin with textual evidence. We can find examples like those in (1) and (2) which show that not all writers agree on which form arises where.

(1) I have never seen so many Daffy Ducks and Mickey Mouses in one place. (McNab, Andy 2008. Cross Fire. London: Corgi, p. 477.)

(2) One specialized in dreadful plastic kitsch; another toys, ten thousand Mickey Mice. (Rathbone, Julian 2001. Homage. London: Allison \& Busby, p. 26.)

I shall take up this question again in relation to my second question in a moment.

Even the most unlikely words can have alterative plurals. In a Peanuts cartoon (Schulz 1960) Linus tells Charlie Brown that they are supposed to make igli at school. When Charlie Brown fails to understand, Linus tells him that igli is a plural: 'one igloo... two igli'. Etymologists, morphologists and language historians will be able to see reasons why ig/i is not a possible plural in English. It may not be possible, but it is occurrent, again, of course, as a joke, but creating alternative plurals where variation would not be expected. But there are other places where multiple plurals are perhaps rather less unexpected. At the period when it was technologically relevant, there was a piece of Unix hardware called a box, and 
its plural, among afficionados, was boxen (remember that the plural of Vax, the computer brand-name, was also Vaxen for a while in similar circles). Many speakers of English are confused not only about the plural but also about the singular in the sequences criterion, criteria, criterions, criterias; phenomenon, phenomena, phenomenons, phenomenas. The Hebrew words goy, kibbutz and Ashkenazican be heard with English plurals or with Hebrew plurals in English, and similar data could be found for Italian words and Arabic words, among others. The plural of octopus can be octopusses, octopodes or octopi, with the etymologically incorrect octopi often being favoured. Words like runner-up can have runners-up or runner-ups as their plural, and text (in places where it means an 'SMS message') can have a variable plural, to simplify the final consonant cluster.

Overall, then, the conclusion for this first part of the presentation is that the forms that fill paradigm slots are not ncessarily unique, and that any theory which provides a single form or assumes that a single form is all that can be expected is likely to be insufficient.

\section{QUESTION 2: WHAT ARE THE RULES FOR REGULAR INFLECTION OF OTHERWISE IRREGULARLY INFLECTED WORDS?}

This question assumes that it is true that irregular forms can be regularly inflected some of the time, and then makes the further assumption that the regularly inflected variants are likely to arise in predictable places. In other words, although different plurals may arise in different environments, they are probably in complementary distribution. And, indeed, we find clues in the literature as to where regular inflection might be found under such circumstances, although the implication is that where we find regular inflection we do not have the same lexical item that we have when the irregular inflection occurs. Four cases are given where this might be expected.

(a) When the expected irregularity occurs within a name (e.g. Mickey Mouse) - see PINKER (1999, p. 149), where it is implied that this is an absolute rule, although Pinker later moderates this position.

(b) When the expected irregularity occurs within a bahuvrihi or exocentric compound (e.g. lowlife, sabretooth) - see KIPARSKY (1982, p. 10), PINKER (1999, p. 171).

(c) Where the expected irregularity occurs on a noun which has a figurative reading (e.g. computer mouse) - see PINKER (1999, p. 174), although he goes on to provide an alternative reason.

(d) Where a verb with irregular inflection is changed into a noun by conversion and then again converted into a verb (e.g. to grandstand) - see KIPARSKY (1982, p. 10), PINKER (1999, p. 165). 
In every case, the justification is the same: the form which is normally irregularly inflected is no longer in head position, and therefore cannot transmit information about its irregularity to the lexical item in which it now occurs. It is nice to have a solid justification for this, and it is nice to see that the predicted positions for the regular forms match the cases we have already discussed (with the exception of grandstanded, which has not yet been mentioned).

We have already seen, though, that the textual evidence does not always match the theoretical position outlined here with relation to names (see (1) and (2) above). If we look more widely, we can find the data in Figure 1 from Google ngrams (books.google.co/ngrams). Although Figure 1 shows a lot of variation (the big jump from one year to another surely caused by relatively low numbers of hits), the result does not seem to match the prediction: the irregularly inflected form arises far more often than is predicted by the theoretical stance.

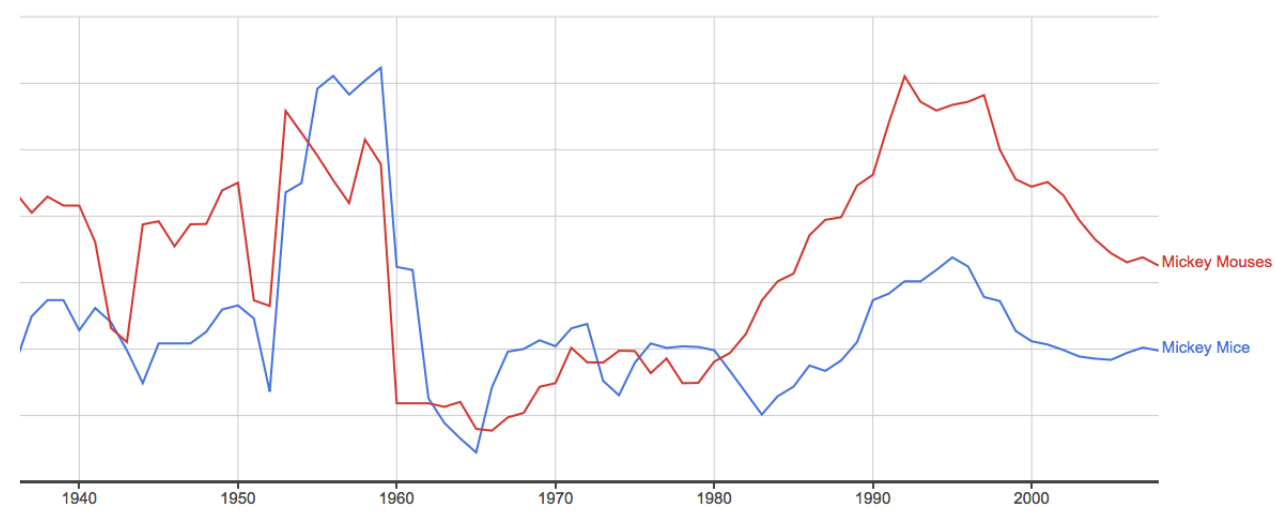

Figure 1. Mickey Mouses versus Mickey Mice in Google ngrams.

If we now turn our attention to the so-called exocentric compounds, we find corpus evidence like that in (3)-(4), taken from The Corpus of Contemporary American English COCA - DAVIES (2008).

(3) the grotesquely fertile soil that sends grasses and broadleaves up through the courts' surface by main force

(4) The forest of emerald evergreens and golden broadleafs bore a silence so deep as to seem deafening

BAUER et al. (2013, p. 133) report flatfoots 'policemen' alternating with flatfeet, and tenderfoots ('beginners') alternating with tenderfeet. Further textual examples are in (5)-(6). 
(5) Native Americans have been living in the are for over ten thousand years. The Cheyenne, Kiowa, Shoshone, Blackfeet and, more recently, the Crows. (Rollins, James 2011. The devil colony. New York: William Morrow, p. 372).

(6) "Can you do others?"

"You mean portraits besides yours? Believe it or not, I can."

"No, I mean - animals, you know, or still lifes. Lives." (Finn, J.A. 2018. The woman in the window. New York: William Morrow, p. 90)

Where figurative use is concerned, we can again find Google data on computer mice and computer mouses, as in Figure 2.

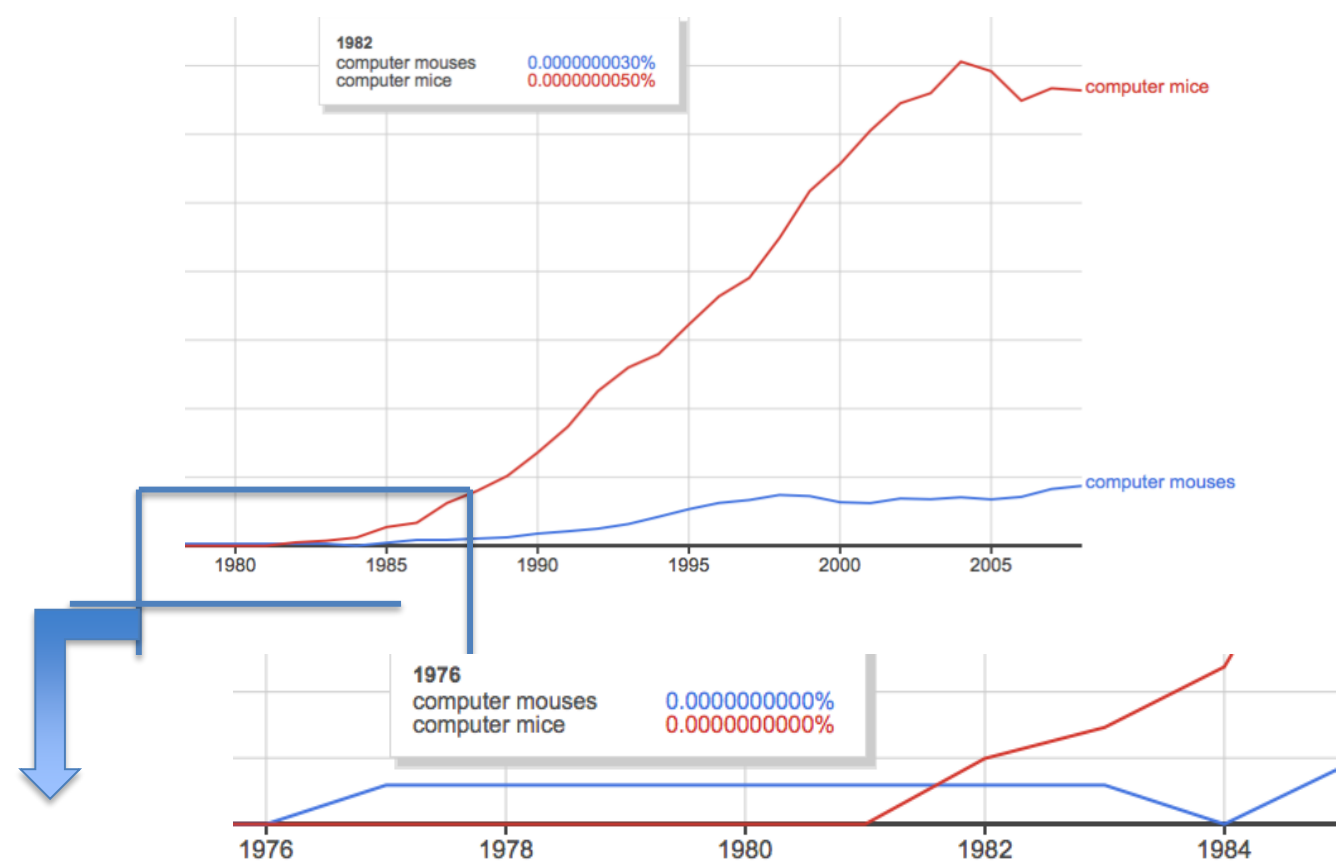

Figure 2. Computer mouses versus computer mice in Google ngrams.

Apart from the fact that both forms are used, the call-out at the bottom of the figure seems to show that the regular plural was more common in early usage, and that gradually the irregular plural has become more dominant as the sense of mouse as a figurative expression has waned. Nevertheless, variation persists. With other figurative uses, we also seem to find a certain amount of variation, as shown in (7)-(8).

(7) Our gooses were constantly getting bumped (COCA)

(8) the anti-tobacco politicos had cooked their geese (COCA)

(The example in (7) contains an expression which is unfamiliar to me, personally, but seems to be figurative.) 
Finally, we can consider cases like the grandstanded one. The general rule is that where an irregular verb is used as the head of a construction, it maintains its irregularity, so that the past tense of understand is understood, even though understand no longer contains any of the meaning typically associated with stand. However, where an irregular verb is converted into a noun and then the noun is converted into a verb, the link to the irregularity is lost. The verb stand gives the noun stand, from which we create the compound grandstand, and this noun is then converted into a verb, but because it has passed through the noun stage, we find grandstanded and not * grandstood. Light is, in some varieties of English, an irregular verb, with past tense and past participle lit. There is also a noun light, from which we get the noun floodlight, and that can be converted into a verb, whose past tense is floodlit. The verb light also gives rise to another compound verb, to highlight. Highlight is a regular verb, with past tense and past participle highlighted. (WEHMEIER 2000). These are precisely the wrong way round for the predictions from understand and grandstand. Appropriate examples are not particularly common, and in some case, both regular and irregular inflection is found, but there is at least variation in what is found here.

PINKER (1999: 171) concludes that "people do in fact regularize rootless and headless words. At worst, the exceptions force us to say that regularization is a real effect but only a statistical one." We can rephrase this as saying that while variation is acknowledged, the patterns are seen as more important. My conclusion here is different. It is that while there may be constructions which make regular inflection more likely, variability is endemic, and neither construction nor lexeme provides sufficient information to allow prediction of regular versus irregular inflection. There may be preferences and tendencies, but there are no rules.

English is a language which, as is well-known, has a rather restricted inflectional morphology. Other languages provide rather more data. THORNTON (2011, 2012a, 2012b) considers what she calls overabundance in Italian inflection; German has an alternation between - $s$ and -es as markers of the genitive case, and, in more conservative usage, alternation between $-\varnothing$ and - $e$ for dative singulars. The English examples are enough to show that the problem is not trivial, but other examples show that it is so important that it must somehow be built in to our descriptive mechanisms and our theoretical models.

\section{QUESTION 3: WHAT IS THE WORD FOR ᄀADJECTIVE?}

This question is, again, a specific version of a more general question. The assumption underlying the question is that there must be a unique output for a given semantic or onomasiological input. The onomasiologists themselves know that this is not the case (see, e.g., ŠTEKAUER 2005, Ch 2). In English, negative adjectives seem to be particularly 
prone to variation, which is why they have been chosen as an illustration here. But there are many other examples that could be considered. Nominalisations of verbs, for instance: English has commission, commissure, committal, commitment as nominalisations of commit, for instance, and although they can be used to distinguish meanings, they can also overlap in meaning. To see something of the extent of the variation, consider the data in Table 1 from the Oxford English Dictionary.

\begin{tabular}{|c|c|c|}
\hline a- & in- & un- \\
\hline $\begin{array}{c}\text { ahistorical } \\
\text { anhistorical }\end{array}$ & & unhistorical \\
\hline alogical & illogical & unlogical \\
\hline apolitical & impolitical & unpolitical \\
\hline & impolite & upolie \\
\hline & improper & unproper \\
\hline & irredeemable & untypical \\
\hline atypical & & \\
\hline
\end{tabular}

Table 1. Variable morphological form for negative adjectives in the OED

If we look at corpus data, we find the examples in (9) from COCA, where those words followed by a parenthesised $(O)$ are also listed in the Oxford English Dictionary (and therefore are not, or may not be, invented by the speaker/writer on the spur of the moment). Although all of these adjectives show the negative prefix in-, I think it would be safe to say that un-is probably the expected form for all of them. Despite that, variation is the order of the day.

(9) inadapted, inapparent $(\mathrm{O})$, inappeasable $(\mathrm{O})$, inarguable $(\mathrm{O})$, inartful $(\mathrm{O})$, inartistic $(\mathrm{O})$, inassimilable $(\mathrm{O})$, incivil $(\mathrm{O})$, indemonstrable $(\mathrm{O})$, inequal $(\mathrm{O})$, infathomable, infavorable, ingenerous, inimaginable, inintelligent, ininteresting, instable $(\mathrm{O})$, intenable

What we see here is that, as with inflectional morphology, the exponents of derivational categories are not necessarily predictable on a lexical basis. Overabundance applies to derivational paradigms as well as to inflectional ones.

\section{QUESTION 4: WHICH ALLOMORPH OCCURS / $\mathrm{X}_{--} \mathrm{Y}$ ?}

Part of the definition of allomorphs is that they occur in complementary distribution. The complementary distribution may be conditioned phonologically, lexically or in some other manner. The canonical allomorph is conditioned phonologically, and some authorities (e.g. Fábregas \& Scalise 2012: 16) allow for allomorphy only when it is 
phonologically conditioned. Against this background, we can consider some phonologically conditioned allomorphy in English.

As a first example, consider the prefix en-, which has an allomorph em-. The allomorph em-is generally stated to occur immediately before a bilabial, with en-being the elsewhere form (see e.g. BAUER et al. 2013: 14). This gives us the expected forms embark ('get on a boat'), emplane ('get on a plane'), entrain ('get on a train') and so on. However, we also find the examples in (10), where $(G)$ stands for 'general' (enmesh can be found in any dictionary of English, with some allowing emmesh as a dispreferred alternative), and COCA and BNC stand for the two big corpora (DAVIES 2004, 2008). The fact that enplane is found in both COCA and the BNC suggests that, although rare, it is not just a random error.

(10) enmesh $(G)$, enmired (COCA), enmagicked (COCA), enplane(d) (COCA, BNC), enpool (COCA), enpewed (COCA)

We can also consider the negative prefix in-. It has a wider range of allomorphs, set out in orthographic terms in (11).

$$
\begin{aligned}
& \text { (11) } \text { in } \rightarrow \text { ir / _- r } \\
& \text { in } \rightarrow \text { il / _- I } \\
& \text { in } \rightarrow \text { im / _- [bilabial] } \\
& \text { in } \rightarrow \text { in / elsewhere }
\end{aligned}
$$

Although the rule is specified in orthographic form in (11), it can be specified in as much detail, or in rather closer phonetic detail, in phonological terms if required. The orthographic version provides all the information we require for the presentation here. The rules in (11) give us the expected forms in (12).

(12) irreparable, illegitimate, improbable, inevitable

Corpus and dictionary data also provides the examples in (13).

(13) inbalance, inbearable, inbelievable, inperfections, inpracticable (COCA), inpronounciable ${ }^{\dagger}(\mathrm{OED})$

It must be admitted that the corpus data here is rather less robust than some of the other corpus data provided in this paper. Since I and $U$ and also $\mathrm{N}$ and $\mathrm{M}$ are adjacent letters on the computer keyboard, there are two routes by which these forms could have arisen as simple typographical errors. Nevertheless, there is sufficient data here to suggest that the 
exponents of derivational (and also inflectional) categories are not necessarily predictable on a phonological basis: allomorphy patterns are not immutable.

\section{QUESTION 5: IS -NESS MORE PRODUCTIVE THAN -ITY?}

Yet again, this question is a specific version of a more general question: can we measure the comparative productivity of any two morphological processes? Productivity, the degree to which a particular process is used, is a matter which has generated a lot of interest among morphologists, and which tends to be ignored by phonologists and syntacticians. As someone who has contributed to the debate on morphological productivity (e.g. BAUER 2006), I have a vested interest in this question, and I approach the question - as I have approached all the questions in this paper - clearly from the perspective of a morphologist. Having said that, I will signal briefly that I consider that productivity to be a topic which has a wider application. In an early paper (BAUER 1978) I argued for the use of productivity in morphophonemic studies as providing a limit to abstractness. Where syntax is concerned, consider the use of the passive. In both English and Maori, there is a passive which is derived from an active form: the derivation is periphrastic in English and morphological in Maori. In British English, on the basis of texts produced in the 1950s and 1960s, Svartvik (1966) says that the passive is used 32 per cent of the time in his scientific text, but no more than 7 percent of the time in fiction. Given the current prescription against the use of the passive, I would expect the usage in science to be lower today than it was then. In Maori, one count for traditional Maori usage puts the usage at approximately 70 per cent of available verbs in narrative texts (W. Baver, personal communication). I find it unsatisfactory to treat these two in precisely the same way, because to do so hides a very salient difference between the syntax of the two languages, and I suggest that the difference is a matter of productivity. However, I shall not follow up on this point here, and I return to the question as stated in the section heading.

I begin the investigation by looking at some corpus data on the use of -ness and -ity in English. Here I have simply looked at the numbers of hits for word-types ending in -ness or - ity on bases which appear to end in a range of different suffixes. I recognize that this is not a very sophisticated form of analysis, and suggest that the results should be taken to exaggerate such differences as there are. Nevertheless, it seems to me that the results set out in Table 2 are suggestive of different uses of -ness and -ity (or, at least, of past uses of these suffixes: data on current productive usage is much harder to collect). 


\begin{tabular}{|l|l|l|l|}
\hline \multicolumn{2}{|c|}{-ity preferred } & \multicolumn{2}{c|}{-ness prefered } \\
\hline -ality & $>1000$ & -antness & 6 \\
\hline -alness & 91 & -antity & only quantity \\
\hline -arity & 264 & -esqueness & 3 \\
\hline -ariness & 46 & -esquity & 0 \\
\hline -bility & $>1000$ & -fulness & 154 \\
\hline -bleness & 81 & -fulity & 0 \\
\hline -icity & 410 & -ishness & 138 \\
\hline -icness & 35 & -ishity & 0 \\
\hline -inity & 118 & -ousness & 435 \\
\hline -ineness & 9 & -osity & 133 \\
\hline -ority & 226 & -someness & 32 \\
\hline -oriness & 15 & -somity & 0 \\
\hline & & & \\
\hline -anity & 86 & -oidness & 0 \\
\hline -anness & 57 & -oidity & 0 \\
\hline
\end{tabular}

Table 2. COCA data on affix sequences in English.

Above the break in Table 2, there are preferences, sometimes for -ity, sometimes for-ness; below the break, the numbers are much more equal. It should be noted that the pattern of preference does not simply reflect the distinction between boundary types or strata that were used in earlier phonological models.

Such patterns have, of course, been observed before (e.g. ANSHEN \& ARONOFF 1988), and have been used to support a range of theories. Here I shall simply say that it is not enough to say that affixes (or other word-formation processes) are productive or not: they are productive in different domains. The domains illustrated in Table 2 are domains created by previous affixation, but other domain types are also possible. For example, the suffix -er can be used in English to create locative nouns as in (US) diner 'a place where one eats', and can also be used to create agent nouns such as killer 'a person or thing that kills'. The first of these is not very productive, while the latter is extremely productive. This then, illustrates a domain based on the meaning of the affix (although it is usually said that the same affix is involved in the two instances). Domains can also be based on phonological patterns (e.g. stress patterns, or the presence of particular consonant types).

Any attempt to give a measure of the productivity of 'an affix' can, therefore, not give more than an average over whatever domains the relevant affix inhabits. Averaging out in this way inevitably means that information is lost. Furthermore, it is not clear whether the overall number of words formed or the overall number of domains in which words can be formed is the more important in estimating productivity. We do not even know whether the answer is always the same or, whether it is or not, how to derive a measure of productivity which appropriately takes account of both.

If you cannot measure morphological productivity accurately for an individual affix, or for two distinct affixes that share domains (even if we can allow that we can give impressionistic 
statements of relative productivity of affixes - as I did above with -er in different domains), it must follow that you cannot compare the productivity of affixes from different domains in an accurate manner. Thus questions like those in (14) must be meaningless.

(14) a. Is -ness more productive than -er, and if so by how much?

b. Is -erin German more productive than -erin English?

The trouble with this conclusion is that answers to the questions in (14) would be useful. If nowhere else, they would be useful in language-teaching situations, where it would be helpful to be able to give students a list of the five (or ten) most productive word-formation patterns, or of the five most productive prefixes, and where it would be useful to be able to tell German learners of English (or vice versa) whether to use a particular suffix more or less often than they would in their own language. Of course, answers to questions like (14a) have been given (e.g. by BAAYEN \& LIEBER 1991), but only by producing the averaging effect that I have just criticized, and thus by losing some relevant information.

\section{QUESTION 6: IS -TH]N PRODUCTIVE?}

My last question in this paper is another one which is a specific version of a more general question. The question is raised from time to time with the English suffixes - ment (as in accompaniment) and -a/ (as in arriva), and with the prefix $a$ - (as in atypical, but also as in aflutter). The place where it is most frequently raised, though, and therefore the case I will consider here, is with the suffix - th that produces nouns, as in warmth.

We can begin with data from the OED on the most recent formations with - th in the dictionary. The last recorded formations are those in (15).

(15) gloomth (Walpole) 1753

greenth (Walpole) 1753

blueth (Walpole) 1754

builth (< build) 1805

illth 1862

On the face of it, this suggests that -th is no longer productive. The question that always arises in this context, though, is the word coolth (to match warmth). Many people feel that it is a form which has been recently invented. The OED, however, has records of coolth from 1547 onwards. It is suggested there that more recent uses of the word are recreations, in effect new formations with -th. It is hard to know. More recent uses of coolth, cited in the 
$O E D$, suggest a certain degree of levity is involved with the words, as illustrated in (16). Such recurrent levity might suggest some familiarity, since it is not inherent in the morphology.

(16) The current coolth, which shows signs of losing its facetiousness, and may claim part of the territory of cool. (JRR Tolkien)

Hear it we did, in the coolth of the evening, as twilight spread her violet veils across the garden. (Elizabeth Peters)

My personal feeling is that the most likely scenario is that coolth has been in the linguistic environment since the sixteenth century, and is not being reinvented in every generation. That is, despite its relative rarity, coolth recurs often enough for speakers to have some familiarity with it and its connotations. The point is, though, that it is hard to be sure. We cannot be sure that it is not productive, but even if we found a genuinely new form with -th being created by some twenty-first century Walpole, neither could we be sure that it was really productive in our society. It behooves us to remember the salutary tale of the suffix-dom. The suffix-dom was thought to be dead in the late nineteenth and early twentieth century, and it took a paper by WENTWORTH (1941) to demonstrate that while its demise had been being mourned, it has actually been thriving, with a constant stream of new words being formed, and reports of its death had been greatly exaggerated. It is perhaps relatively easy to image a resurrection of -th because (at least in some of its formations - warmth if not filth) we can see a transparent pattern. Those patterns which are least likely to be resurrected are those where current speakers no longer see any pattern (forms such as cockerel, once a diminutive, maiden, also a diminutive, and sparkle, an iterative, with many words still in the English vocabulary, are less likely models for new formations because the patterns they once represented are no longer perceived as patterns at all).

In short, the borderline between productive and unproductive is often very difficult to spot, marginal productivity is still important and still productivity (BAUER 2015), and it is dangerous to assume that any recognizable pattern is completely defunct.

\section{CONCLUSION}

In this paper I have tried to show that some of the notions that we hold most dear in morphology are notions which it is worth challenging. In particular, notions of rule may not be the best way of formulating insights into linguistic behavior, because rules demand fixed outcomes: they either generate or do not generate particular constructions, they do not allow for unpredictable variability (see also PULLUM 2020). Real language use allows for 
more synonymy and homonymy than even practised observers may believe. Good linguistic description has to allow for tendencies as well as for definitive outcomes.

Most importantly, we have to take care with the questions that we ask when setting up our theories. Very often we end up by constraining our theories, and even our descriptions, sometimes in undesirable ways, by asking the wrong questions. Finding better questions to ask has the potential to lead to an improved understanding of the way in which humans really use language.

\section{ACKNOWLEDGEMENTS}

This contribution is a lightly revised version of a plenary presented at the European Linguistics Society in Poznan, Poland, in 2014, and then presented through the ABRALIN online lecture series in July 2020. The paper has never been published before, although some of the data has been used in other work, in one form or another. The work and travel for the original presentation were supported by the Royal Society of New Zealand's Marsden Fund, the Societas Linguistica Europea, and the Spanish Ministerio de Economía y Competitivdad, whose support is greatly appreciated.

\section{REFERENCES}

ANSHEN, Frank; ARONOFF, Mark 1988. Producing morphologically complex words. Linguistics v. 26, p. 641655, 1988.

BAAYEN, R. Harald; LIEBER, Rochelle. Productivity and English derivation: A corpus-based study. Linguistics 29, p. 801-843, 1991.

BAUER, Laurie. On lexicalization. Archivum Linguisticum, v. 9, p. 3-14, 1978

Baver, Laurie. Morphological productivity. Cambridge: Cambridge University Press, 2006. https://doi.org/10.1017/CBO9780511486210

BAUER, Laurie. The importance of marginal productivity. SKASE Journal of Theoretical Linguistics v. 12 n. 1, p. 72-77, 2015. http://www.skase.sk/Volumes/JTL27/pdf_doc/05.pdf

BAUER, Laurie; LIEBER, Rochelle; PLAG, Ingo. The Oxford reference guide to English morphology. Oxford: Oxford University Press, 2013. DOI:10.1093/acprof:oso/9780198747062.001.0001

DAVIES, Mark. The British national corpus (BNC), 2004. https://www.english-corpora.org/bnc/

DAVIES, Mark. The corpus of contemporary American English (COCA), 2008. https://www.englishcorpora.org/coca/

FÁBREGAS, Antonio; SCALISE, Sergio. Morphology: From data to theories. Edinburgh: Edinburgh University Press, 2012. 
KIPARSKY, Paul 1982. Lexical Morphology and Phonology. In: THE LINGUISTIC SOCIETY OF KOREA (ed.), Linguistics in the morning calm. Seoul: Hanshin, 1982, p. 3-91.

PALMER, Frank; HUDDLESTON, Rodney; PULLUM, Geoffrey K. Inflectional morphology and related matters. In: HUDDLESTON, Rodney; PULLUM, Geoffrey K. (eds), The Cambridge grammar of the English language. Cambridge: Cambridge University Press, 2002, p. 1565-1609.

PINKER, Stephen. Words and rules. London: Weidenfeld \& Nicolson, 1999.

PULLUM, Geoffrey K. Theorizing about the syntax of human language: a radical alternative to generative formalisms. Cadernos de Linguistica v. 1, n. 1, 2020

https://cadernos.abralin.org/index.php/cadernos/article/view/279 accessed 20 August 2020.

QUIRK, Randolph; GREENBAUM, Sidney; LEECH, Geoffrey; SVARTVIK, Jan. A grammar of contemporary English. London: Longman, 1972.

SCHULZ, Charles. Peanuts cartoon for $25^{\text {th }}$ January, 1960. https://www.gocomics.com/peanuts/1960/01/25 accessed 20 July 2020.

ŠTEKAUER, Pavol 2005. Meaning predictability in word formation. Amsterdam and Philadelphia: Benjamins, 2005. https://doi.org/10.1075/sfsl.54

STRANG, Barbara M.H. Modern English structure. London: Arnold, 1969

SVARTVIK, Jan. On voice in the English verb. The Hague and Paris: Mouton, 1966.

THORNTON, Anna M. 2011. Overabundance (multiple forms realizing the same cell): a noncanonical phenomenon in Italian morphology. In: MAIDEN, Martin; SMITH, John Charles; GOLDBACH, Maria \& HINZELI, Marc-Olivier (eds), Morphological autonomy: Perspectives from Romance inflectional morphology, Oxford: Oxford University Press, 2011, p. 358-381.

THORNTON, Anna M. Overabundance in Italian verb morphology and its interactions with other non-canonical phenomena. In: STOLZ, Thomas; OTSUKA, Hitomi; URDZE, Aine; VAN DER AUWERA, Johan (eds), Irregularity in morphology (and beyond), Berlin: Akademie, 2012a, p. 251-269.

THORNTON, Anna M. Reduction and maintenance of overabundance. A case study on Italian verb paradigms. Word Structure v. 5, 2012b, p. 183-207. DOI: 10.3366/word.2012.0026

WEHMEIER, Sally (ed.). Oxford advanced learner's dictionary. $6^{\text {th }}$ edition. Oxford: Oxford University Press, 2000

WENTWORTH Harold. The allegedly dead suffix -DOM in modern English. Publications of the Modern Language Association, v. 56, p. 280-306, 1941. 